RUDOLPH, KURT W., Univ. Texas, Austin, Tex.

Diagenesis of Back-Reef Carbonate Rocks-Example from Capitan Complex

The lower Tansill Formation (Permian) in the vicinity of Carlsbad Caverns, New Mexico, is a basinward prograding sequence of back-reef carbonate rocks equivalent to the Capitan reef. Toward the north (shelfward), the facies tract consists of outer-shelf skeletal-intraclast grainstone, shelf-crest pisolite, and lagoonal pelletal dolomite. Diagenesis occurred by means of four phases that reflect the changing hydrologic regime. Squareended ray cement (phase I), now calcite or dolomite, but originally aragonite, was the product of marine wa. ters. Calcitized ray cement from the reef has retained up to 3,500 ppm strontium and has a relatively heavy carbon and oxygen isotopic composition. Back-reef examples are lower in strontium and lighter isotopically, reflecting neomorphism under more open conditions by meteoric water.

Soon after deposition, outer-shelf and shelf-crest sediment was periodically exposed to fresh water (phase II). Calcite cement that is the product of this early meteoricschizohaline regime is nonluminescent, has low or variable magnesium content, and has an intermediate isotopic composition. Contemporaneous diagenetic processes include solution, conversion of aragonite to calcite, and schizohaline dolomitization. Perhaps reflecting its genesis, the strontium content of Tansill dolomite increases shelfward from the shelf crest, which was the area of meteoric recharge. As back-reef carbonate deposits became buried, meteoric conditions became more stable in the shallow subsurface (phase III). Phase III calcite cement is luminescent, uniformly low in magnesium, and has a relatively light isotopic composition. Upon erosion of the overlying sediment, the rocks were subjected to near-surface meteoric flushing, resulting in solution and minor cementation (phase IV).

RUTLEDGE, C., Wyoming Mineral Corp., Lakewood, Colo.

In-Situ Uranium Solution Mining-Environmental and Licensing Regulations

Under changing conditions, the structure of state or federal regulatory agencies, their resources and authority, and their people and how they function also are subject to changing responsibilities.

Similarly, a typical vigorous mining corporation utilizing newly developing technology changes with respect to its organization and objectives, its employees and their attitude, plus the economic principles and competition which motivate the company's method of operation. The interaction of the government agency and the firm finds concomitant changes in the outcome of the divergent forces and demands on each. Of particular importance are the provisions of rules, regulations, and permits produced under these circumstances, as well as the company's responses to them.

RYER, THOMAS A., U.S. Geol. Survey, Denver, Colo.

Deltaic Coals of Ferron Sandstone Member of Mancos Shale-Predictive Model for Cretaceous Coals of

\section{Western Interior}

Superb exposures of the Upper Cretaceous Ferron Sandstone Member of the Mancos Shale in southern Castle Valley, Utah, record rapid accumulation of clastic sediments in a suite of deltaic environments that existed along the western margin of the Interior Cretaceous seaway during late Turonian time. The Ferron consists of five major delta cycles. Each cycle records northeastward progradation of a high-constructive delta followed by phases of abandonment and destruction. A clear genetic relation exists between these deltaic cycles and the economically important coal beds of the Ferron, each cycle containing one thick bed of coal. Several of the coal beds contain one or more laterally continuous kaolinitic claystone partings that record falls of volcanic ash into the low-energy swamp environment. These partings, viewed as time lines, permit detailed reconstructions of the histories of individual swamps. Two of the thickest claystone partings have been traced southwest beyond the landward limits of the peat-forming environment into noncarbonaceous facies and have been used to establish equivalency of facies. Further, it can be demonstrated that the thickest part of each of the coal beds is in a position just landward of the southwestward pinchout of its associated delta-front sandstone. This genetic relation forms the basis of a predictive model that can be used to guide exploratory drilling programs in Cretaceous coal-bearing rocks of the Western Interior.

SACKETT, WILliAM M., Texas A\&M Univ., College Station, Tex.

\section{Stable Carbon Isotopes as Paleoclimatological Tool}

The dependence of the stable carbon isotope composition of plankton on water temperature forms the basis of a paleoclimatological tool useful for deep-sea sediments. Detailed work on a 12-m core (E-49-30) taken from a depth of $4,200 \mathrm{~m}$ at $59^{\circ} 0.3^{\prime} \mathrm{S}, 95^{\circ} 13.8^{\prime} \mathrm{E}$, shows a trend in $\delta^{13} C_{\mathrm{PDB}}$ for total organic carbon from approximately -22 parts per thousand at the top to -28 parts per thousand at the bottom. Several systematic excursions to about -18 parts per thousand occur at intermediate depths. The most obvious explanation for the primary trend is a general increase in the amounts of warm-water plankton residues, relative to those of cold water, deposited at this location over the time represented by these sediments (about $1 \mathrm{~m}$.y.). This increase implies a southward migration of the Polar Front.

Two other cores (28-266, 28-272) taken near Antarctica during the Deep Sea Drilling Project show similar trends which, presumably, are due to the same process.

Advantages of this potential tool are that it is directly related to surface water temperatures and is especially useful for carbonate-free sediments. Disadvantages include an incomplete understanding of the factors which determine modern carbon isotope compositions of plankton, kerogen recycling near the Antarctic continent, and obliteration of the paleotemperature signal by terrestrial, plant-derived organic matter deposited contemporaneously with the plankton-derived organic matter. 